\title{
SAPHO syndrome with mandibular manifestation
}

\author{
Akira Baba, ${ }^{1}$ Hiroya Ojiri, ${ }^{2}$ Shinichi Takahashi, ${ }^{3}$ Akira Katakura ${ }^{4}$
}

'Department of Radiology, Tokyo Dental College, Ichikawa General Hospital, Chiba, Japan ${ }^{2}$ Department of Radiology, The Jikei University School of Medicine and University Hospital, Tokyo, Japan ${ }^{3}$ Department of Dermatology, Tokyo Dental College, Ichikawa General Hospital, Chiba, Japan ${ }^{4}$ Department of Oral Pathobiological Science and Surgery, Tokyo Dental College, Tokyo, Japan

\section{Correspondence to} Dr Akira Baba, akirababa@jikei.ac.jp

Accepted 12 December 2015

\section{DESCRIPTIONF}

A 47-year-old man was referred to our hospital due to symptoms of trismus and exacerbation of palmoplantar pustulosis. He had been presenting, for 20 years, with refractory and recurrent mandibular osteomyelitis accompanied by palmoplantar pustulosis and anterior chest pain-symptomatic treatment and surgery had been given at each

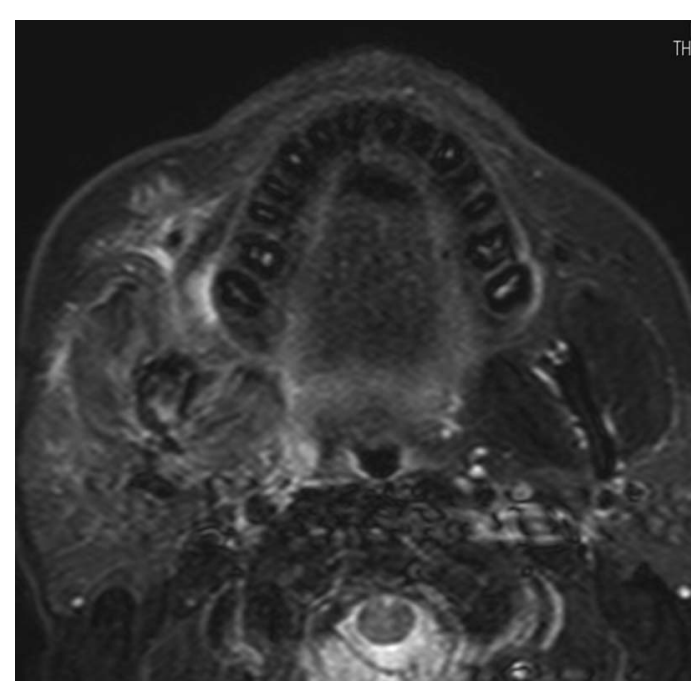

Figure 1 MRI (short tau inversion recovery) showed high signal intensity in the right ramus of the mandible, with perilesional soft tissue swelling. presentation. When the mandibular lesion got worse this time, he also had anterior chest pain. $\mathrm{He}$ had experienced similar episodes before this event. MRI (STIR: short tau inversion recovery) showed high signal intensity in the right ramus of the mandible, with perilesional soft tissue swelling (figure 1). These findings indicated active mandibular osteomyelitis. SAPHO syndrome was suggested by the clinical course and history. Bone scintigraphy using $99 \mathrm{mTc}$-methylenediphosphonate (MDP) was performed and increased tracer uptake was seen in the right ramus of the mandible, greater wing of sphenoid bone, sternum and the sternocostoclavicular joints (figure 2). These characteristic clinical and radiological findings were compatible with the diagnosis of SAPHO syndrome involving the mandibular region. The term SAPHO syndrome was coined in 1987 to describe an association of characteristic bone, joint and skin lesions. ' 'SAPHO' is an acronym for synovitis, acne, palmoplantar pustulosis, hyperostosis and osteitis. Its aetiology remains unknown. ${ }^{12}$ The sternocostoclavicular, sternoclavicular, costoclavicular and manubriosternal joints are affected. ${ }^{3}$ Bone scintigraphy using $99 \mathrm{mTc}-\mathrm{MDP}$ is known to be important for diagnosis of this disease. SAPHO syndrome in the mandibular region is clinically rare and has been reported to be $10 \%$ of this entity. ${ }^{1}$ SAPHO syndrome in the mandibular region is seen as recurrent mandibular osteomyelitis, mainly involving the body of the mandible. ${ }^{2}$ In patients with clinical and radiological evidence of SAPHO syndrome, when recurrent mandibular
To cite: Baba $A$, Ojiri $H$, Takahashi S, et al. BMJ Case Rep Published online: [please include Day Month Year] doi:10.1136/bcr-2015213401



Figure 2 Bone scintigraphy using 99mTc-methylenediphosphonate revealed increased tracer uptake in the right ramus of the mandible, greater wing of sphenoid bone, sternum and the sternocostoclavicular joints.




osteomyelitis is also present, it should be considered as a part of SAPHO syndrome.

\section{Learning points}

- SAPHO syndrome involving the mandible is clinically rare and has been reported to be $10 \%$ of this entity.

- SAPHO syndrome in the mandibular region is seen as recurrent mandibular osteomyelitis, mainly involving the body of the mandible.

- In patients with evidence of SAPHO syndrome, when recurrent mandibular osteomyelitis is also present, it should be considered as a part of SAPHO syndrome.
Contributors $A B$ drafted the paper, and collected data and reviewed the text. All the authors diagnosed the disease, read and approved the final manuscript. ST and AK treated the patient and helped $A B$ draft the paper. $\mathrm{HO}$ made the final revision.

Competing interests None declared.

Patient consent Obtained.

Provenance and peer review Not commissioned; externally peer reviewed.

\section{REFERENCES}

1 Chamot AM, Benhamou CL, Kahn MF et al. [Acne-pustulosis-hyperostosis-osteitis syndrome. Results of a national survey. 85 cases]. Rev Rhum Mal Osteoartic 1987:54:187-96.

2 Zemann W, Pau M, Feichtinger $M$ et al. SAPHO syndrome with affection of the mandible: diagnosis, treatment, and review of literature. Oral Surg Oral Med Oral Pathol Oral Radiol Endod 2011;111:190-5.

3 Kundu BK, Naik AK, Bhargava $S$ et al. Diagnosing the SAPHO syndrome: a report of three cases and review of literature. Clin Rheumatol 2013;32:1237-43.

Copyright 2015 BMJ Publishing Group. All rights reserved. For permission to reuse any of this content visit http://group.bmj.com/group/rights-licensing/permissions.

BMJ Case Report Fellows may re-use this article for personal use and teaching without any further permission.

Become a Fellow of BMJ Case Reports today and you can:

- Submit as many cases as you like

- Enjoy fast sympathetic peer review and rapid publication of accepted articles

- Access all the published articles

- Re-use any of the published material for personal use and teaching without further permission

For information on Institutional Fellowships contact consortiasales@bmjgroup.com

Visit casereports.bmj.com for more articles like this and to become a Fellow 